\title{
APLIKASI TEKNOLOGI FERMENTASI KULIT BUAH COKLAT UNTUK MENINGKATKAN KUALITAS PAKAN TERNAK DI NAGARI LURAH AMPALU KECAMATAN VII KOTO PADANG PARIAMAN
}

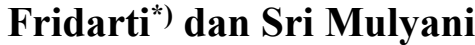 \\ Fakultas Pertanian Universitas Tamansiswa Padang \\ *)Email : fridartifridarti69@gmail.com
}

\begin{abstract}
ABSTRAK
Nagari Lurah Ampalu merupakan salah satu sentra produksi coklat(cacao) yang terbesar di Sumatera Barat, dengan demikian limbah kulit buah coklat cukup banyak tersedia tapi belum memanfaatkan dengan optimal, Untuk perlu penyuluhan tentang teknologi sederhana yang dapat dipergunakan dalam pengolahan limbah tersebut. Salah satu teknologinya adalah fermentasi dalam pengabdian masyarakat ini menggunakan metode penyuluhan (dialog interaktif) antara masyarakat dengan tim tentang: teknologi fermentasi, Pemanfaatan limbah coklat, pemeliharaan ternak yang baik dan masalah yang dihadapi oleh masyarakat. Hasil kegiatan ini adalah: adanya antusias masyarakat yang tinggi, pendidikan yang masih rendah dengan pengalaman yang sudah cukup lama. Hasil fermentasi cukup baik (bau harum, warna tidak berubah dari asalnya, dan tidak ada jamur) dan hasil pengamatan saat diberikan pada ternak cukup baik dimana ternak sangat menyukai dengan demikian tingkat konsumsi meningkat dan pertambahan berat badan meningkat dengan pemberian $25 \%$ dari Hijauan.
\end{abstract}

Kata Kunci: Nagari, Lurah Ampalu, Fermentasi, Masyarakat, Cacao, Limbah

\section{Chocolate Leather Fermentation Technology Application To Improve Animal Feed Quality In Nagari Lurah Ampalu Kecamatan VII Koto Padang Pariaman}

\begin{abstract}
Nagari Lurah Ampalu is one of the largest cocoa production centers (cacao) in West Sumatra, thus the waste of cocoa pods is quite widely available but has not been optimally utilized. To provide information about simple technology that can be used in processing this waste. One of the technologies is fermentation in this community service using extension methods (interactive dialogue) between the community and the team on: fermentation technology, utilization of cocoa waste, good livestock maintenance and problems faced by the community. The results activity is high community enthusiasm, low education, with long enough experience. The fermentation results are quite good (smell good, the color does not change from the origin, and there is no fungus) and the results of the observations when given to livestock are good enough where the livestock are very fond of it thus the consumption rate increases and weight gain increases with the provision of $25 \%$ of forage.
\end{abstract}

Keywords: Nagari, Lurah Ampalu, Fermentation, Community, Cacao, waste

\section{PENDAHULUAN}

Nagari Lurah Ampalu terletak pada ketinggian antara 5-30 m diatas permukaan laut dengan topografi datar, berbukit dan lereng . Nagari Lurah Ampalu ini berada sekitar $15 \mathrm{~km}$ dari ibu kecamatan Koto VII Padang Pariaman yang terdiri dari 15 Korong dengan luas wilayah sekitar $2.583 \mathrm{Ha}$, jumlah penduduk 6.298 jiwa yang terdiri dari 1.416 Kepala keluarga. Masyarakat daerah ini bermata pencarian adalah bertani dan beternak merupakan pekerjaan sampingan, daerah ini memiliki luas lahan 
perkebunan dan lahan persawahan sekitar $50 \%$ dari luas wilayah nagari, lahan perkebunan ditanam dengan coklat sehingga daerah ini merupakan sentra coklat dengan demikian limbah perkebunan coklat ini berupa kulit buah coklat belum manfaatkan dengan maksimal untuk pakan ternak yang mana biasanya kulit buah coklat ini dibuang begitu saja di lahan perkebunan. Pemanfaatan Kulit buah coklat sebagai pakan ternak dapat diberikan langsung pada ternak atau diolah terlebih dahulu dengan teknologi sederhana yaitu fermentasi dengan menggunakan ragi tape, mikroorganisme indigenus, MOL guna mengurangi anti nutrisi yang terdapat pada kulit buah coklat. Kulit buah coklat mengandung vitamin D yang tinggi, tapi kulit buah coklat juga mengandung suatu zat anti nutrisi yang berupa alkaloid yang disebut Theobromine (3,1 di methil Xantine), (Devendra, 1977). Wong, dkk (1988) menyatakan bahwa kandungan theobromine limbah coklat adalah: Kulit Buah Coklat 0,17 - 0,20\%, Kulit Biji Coklat $1,80-2,10 \%$, dari bahan kering.

Fermentasi adalah suatu proses yang disebabkan oleh mikro-organisme/ enzim yang mengubah bahan-bahan organik kompleks menjadi seperti protein, karbohidrat dan lemak menjadi molekul-molekul yang lebih sederhana dan mudah dicerna sehingga dapat merubah rasa, tekstur, dan aroma yang tidak disukai menjadi disukai ternak (Shurtleff dan Aoyagi, 1979). Fermentasi Kulit buah coklat dengan menggunakan mikroorganisme indigenus dapat meningkatkan aktivitas mikroba rumen (Fridarti. dkk, 2016). Penambahan mineral S dan P dalam fermentasi limbah cacao juga akan meningkatkan aktivitas mikroba dalam cairan rumen (Fridarti dan Mulyani, 2017).

\section{METODOLOGI}

Penerapan Ipteks menggunakan materi: kulit buah coklat, tepung onggok, ragi tape dengan plastic besar sebagai silo, dalam pengabdian masyarakat ini pesertanya adalah masyarakat yang tergabung dalam kelompok tani dan masyarakat yang tidak tergabung dalam kelompok tani.

Metode yang digunakan adalah penyuluhan tentang peternakan (Syaiful, 2019:2020), pakan ternak, pemanfaatan limbah pertanian terutama limbah perkebunan coklat dengan cara dialog interaktif antara team dengan masyarakat peserta, percontohan fermentasi kulit buah coklat, dan praktek langsung oleh peserta bagaimana cara pengolahan kulit buah coklat, pemeraman dilakukan selama 5 hari dan hasil fermentasi diberikan atau dicobakan pada ternak dengan jumlah $15-25 \%$ dari hijauan yang diberikan pada ternk. Perubah yang diamati adalah hasil fermentasi berupa bau, warna, dan tingkat jamur. Sedangkan peubah pada ternak adalah pertambahan berat badan, lingkar dada, panjang badan.

\section{HASIL DAN PEMBAHASAN}

Hasil wawancara dan interaktif pada masyarakat yang hadir saat melakukan penyuluhan maka ditemukan adalah sebagai berikut: 
Website. http://hilirisasi.lppm.unand.ac.id e-ISSN: 2621-7198

\section{Tingkat Pendidikan dan pekerjaan masyarakat}

Rata-rata tingkat pendidikan masyarakat di nagari Lurah Ampalu adalah $46 \%$ tamatan SD dan masyarakat lurah Ampalu masih ada yang buta huruf dan tidak tamat SD yang mana sekitar 5,7 \%, tamatan SLTP 24,7 \% , tamatan SLTA 23,3 \%., serta hanya $1,3 \%$ berpendidikan diploma. Masyarakat dengan bekal pendidikan tamatan SD sudah baik dalam mengelola usaha peternakan walau dalam jumlah sedikit. Hal ini disebabkan petani peternak selalu mendapatkan penyuluhan dari petugas lapangan dan satu kali dalam seminggu selalu mengadakan pertemuan kelompok tani bagi anggota kelompok, pada saat itu mereka selalu bertukar pikiran untuk mendapatkan informasi baru, kemudian disebarluaskan kepada masyarakat di sekitar mereka. Walaupun berpendidikan rendah, hal ini tidak menghambat keinginan masyarakat nagari Lurah Ampalu untuk berusaha memelihara ternak dengan baik, dan mau menerima informasi baru baik yang datang dari penyuluh maupun yang datang dari luar. Ditambahkan oleh Musher ( 1965 ) bahwa pendidikan secara individu adalah penting untuk menerapkan perkembangan baru, cara- cara baru dalam bidang peternakan.

Pekerjaan masyarakat yang terdapat pada Nagari Lurah Ampalu adalah rata rata petani dengan usaha sampingan adalah beternak, ini dapat dilihat pada pengabdian masyarakat bahwa pekerjaan sebagai petani adalah $75 \%$, pedagang $12,5 \%$ dan wira swasta $12,5 \%$ berbekal dengan pengalaman bertani dan beternak secara turun temurun, hal ini tidak menghambat kemauan untuk berusaha memelihara ternak yang baik sesuai dengan petunjuk yang diberikan oleh penyuluh lapangan.

\section{Umur dan Pengalaman Petani Peternak}

Tingkat umur dari petani peternak rata rata berusia produktif yaitu berkisar antara 25 - 65 tahun, dimana usia dibawah 20 tahun hanaya 4,3\%, usia $21-50$ tahun adalah $82.61 \%$ dan usia diatas 50 tahun adalah $13,04 \%$. Dengan usia produktif ini akan mudah dalam penyerap informasi yang baru. Ini terlihat saat pelaksanaan pengabdian mereka sangat antusias dalam menanggapi informasi yang diberikan oleh team. Hal ini sesuai dengan pendapat Adiwilaga ( 1975 ) bahwa umur yang tergolong usia produktif adalah $25-50$ tahun.

Pengalaman petani dalam memelihara ternak cukup lama juga, hal ini terlihat dari hasil pengabdian bahwa pengalaman petani berkisar $5-25$ tahun dimana dibawah 5 tahun hanya sekitar $29,19 \%$, pengalaman $6-15$ tahun $54,16 \%$ dan pengalaman $16-$ 20 tahun $8,33 \%$ dan pengalaman diatas 21 tahun sekitar 8,33\%. Rata rata petani peternak sebelum menamatkan sekolah mereka sudah mendapat ilmu dalam beternak dari orang tua mereka ataupun dari lingkungan mereka, walau usia mereka relatif rendah ( usia produktif ) tetapi pengalaman beternak cukup lama dengan sendirinya mereka lebih mudah dalam menimba ilmu di bidang pertanian maupun bidang lain. Ditambahkan oleh Soeharjo dan Patongan ( 1973 ) bahwa faktor intern yang dapat mempengaruhi sikap peternak dalam menentukan suatu pilihan usaha peternakan terutama pendidikan dan pengalaman. 
Website. http://hilirisasi.lppm.unand.ac.id e-ISSN: 2621-7198

\section{Pengamatan Pemberian Kulit Buah Coklat Fermentasi}

Hasil praktek fermentasi kulit coklat yang menggunakan ragi tape yang dilaksanakan selama pengabdian masyarakat didapat hasil bahwa tidak ada perubahan warna, bau, dan jamur setelah fermentasi kulit buah coklat yang disimpan sampai waktu penyimpanan 5 hari di dalam wadah plastik. Adapun pengamatan pemberian fermentasi kulit coklat fermentasi pada ternak selama pengabdian adalah sebagai berikut:

Tabel 1. Pertambahan Ukuran Badan Ternak Yang Mendapat Kulit Buah Coklat Fermentasi

\begin{tabular}{lcccc}
\hline \multirow{2}{*}{ Variabel } & \multicolumn{2}{c}{ Pengukuran Awal } & \multicolumn{2}{c}{ Pengukuran Akhir } \\
\cline { 2 - 5 } & Tidak & diberi & tidak & diberi \\
\hline Lingkar dada $(\mathrm{cm})$ & 119 & 120 & 129 & 132 \\
Panjang badan $(\mathrm{cm})$ & 82 & 85 & 88 & 102 \\
Tinggi Pundak $(\mathrm{cm})$ & 50 & 97 & 106 & 101 \\
Tinggi Gumba $(\mathrm{cm})$ & 93 & 98 & 109 & 112 \\
Berat Badan $(\mathrm{kg})$ & 198.81 & 201.64 & 216.09 & 240.25 \\
\hline
\end{tabular}

Hasil pengamatan pemberian kulit buah coklat fermentasi pada ternak menujukan perbedaan pertambahan berat badan ternak yang tidak diberi fermentasi kulit buah coklat sekitar $0,576 \mathrm{~kg} / \mathrm{ekor} / \mathrm{hari}$ sedang pertambahan berat badan ternak yang diberi fermentasi kulit buah coklat adalah $0.857 \mathrm{~kg} / \mathrm{ekor} / \mathrm{hari}$. Hal ini menunjukkan bahwa pemberian buah coklat fermentasi dapat meningkatkan pertambahan berat badan ternak, ini disebabkan adanya peningkatan konsumsi makanan.

\section{Tata Laksana Pemeliharaan Sapi.}

a. Jenis bibit dan jumlah ternak

Jenis bibit ternak yang dipelihara oleh petani peternak pada umumnya adalah ternak lokal yang berasal dari pasar ternak yang ada di nagari tersebut, sedangkan sapi simental di dapat dari daerah Bukittinggi dan Payakumbuh. Rata rata petani peternak sebanyak $3-9$ ekor. Jumlah ternak yang dimiliki oleh petani ternak yang kecil dari 3 ekor sekitar 34,77\%, 4 - 9 ekor ternak sapi sekitar 59.09\% dan besar dari 10 ekor sekitar $6,14 \%$. Sapi yang dipelihara oleh petani peternak yang lebih dominan adalah ternak lokal (sapi PO) sekitar 50\% dan sapi simental/ sapi unggul lainnya sekitar 33,3\% sedangkan yang memelihara sapi lokal dan simental ( gabungan lokal dan simental) sekitar $16,7 \%$.

Temperamen dari sapi yang dipelihara oleh petani cukup besar dan mudah beradaptasi dengan lingkungan serta tahan terhadap serangan penyakit. Hal ini sesuai dengan pendapat Abidin ( 2005 ) bahwa ciri ciri ternak bakalan secara umum adalah badan sehat, bentuk tubuh profesional, ditambahkan oleh Sugeng ( 2002 ) bahwa kriteria pemilihan sapi bakalan adalah bangsa dan sifat genetik, bentuk luar, sikap dan tingkah laku. 
Website. http://hilirisasi.lppm.unand.ac.id e-ISSN: 2621-7198

\section{b. Makanan}

Dalam usaha memelihara sapi sangat dibutuhkan hijauan untuk pakan ternak yang mana hijauan tersebut ditanam di sekitar kandang dan di pekarangan rumah, jenis hijauan yang telah mereka tanam adalah jenis rumput unggul walaupun masih ada juga yang menggunakan rumput alam yang didapat di daerah sekitar lahan persawahan dan perkebunan. Luas areal untuk penanaman rumput sekitar 0,5 -1 Ha, yang mana petani yang memiliki lahan kurang dari 0,5 Ha sekitar 59.52\% luas lahan 0,6 - 1 Ha sekitar $39,13 \%$ dan diatas $1 \mathrm{Ha}$ adalah $4,35 \%$. Petani ternak yang sudah memberi rumput unggul kepada ternaknya adalah sekitar $60,87 \%$ sedangkan $39,13 \%$ masih menggunakan rumput lapangan sebagai pakan ternak sapi. Sedangkan konsentrat yang digunakan sebagai bahan pakan penguat dan tambahan adalah sagu, ampas tahu, bungkil kelapa dan dedak padi. Pemberian konsentrat hanya satu kali dalam sehari, jumlah konsentrat yang diberikan pada ternak sapi sekitar 1\% dari berat badan. Yang telah memberikan konsentrat pada ternak sapinya adalah $56.52 \%$ dan yang belum memberikan konsentrat pada ternak sapi adalah $43.48 \%$.

Susetyo ( 1980 ) menyatakan bahwa hijauan merupakan makanan utama bagi ternak ruminansia dan berfungsi tidak hanya sebagai bulk (pengenyang tetapi juga sebagai sumber gizi protein, energi, mineral dan vitamin. Penggunaan hijauan untuk mendapatkan produksi yang tinggi harus ditambahkan dengan makanan penguat (konsentrat ) yang terdiri dari butir - butiran dan biji - bijian seperti kacang - kacangan, serta produk hewan dan hasil ikutan dalam pengelolaan (Speeding, 1971 ).

Tillman ( 1989 ) menyatakan bahwa bahan makanan adalah bahan yang dapat dimakan, dicerna dan digunakan oleh hewan. Makanan sangat berpengaruh terhadap penggemukan anak sapi atau sapi sapi muda, dibutuhkan protein dan energi tinggi dalam ransumnya, karena pertambahan bobot badan dan anak sapi merupakan pertumbuhan otot, tulang dan lemak, hal ini disebabkan sebagian besar pertumbuhan bobot badan sapi dewasa merupakan penimbunan jaringan lemak (Moesofie, 1982 ).

Pemberian hijauan bisa digantikan oleh limbah baik limbah pertanian yang telah mengalami pengolahan, produk yang telah mengalami pengolahan fermentasi yang disebut bokhasi. Ditambahkan oleh Abidin (2005) bahwa upaya untuk meningkatkan pertambahan berat badan harian sapi potong dapat menggunakan berbagai macam cara antara lain adalah penggunaan urea di dalam bahan pakan, bahan pakan yang di fermentasi terlebih dahulu dengan probiotik seperti starbio, bioplus, bossdext dan lain sebagainya yang berguna untuk meningkatkan daya cerna bahan pakan yang mengandung serat kasar yang tinggi.

c. Kandang.

Kandang sapi yang dimiliki petani ternak terbuat dari kayu dengan lantai tanah dengan atap kandang ada dari rumbio dan seng, di dalam kandang dilengkapi oleh tempat makan dan tempat minum. Bentuk kandang adalah berbentuk tunggal yang mana kandang tersebut di sekat-sekat dengan kayu, dalam satu kadang ditempati lebih dari satu ternak dengan ukuran kandang sekitar $3 \times 8 \mathrm{~m}$. Hal ini sesuai dengan fungsi dari kandang yang mana ternak sudah nyaman dalam beristirahat serta terlindung dari panas matahari, hujan. Hal ini sesuai dengan pendapat Abidin (2005) bahwa fungsi kandang adalah: a) melindungi sapi dari gangguan cuaca panas, hujan, udara dingin serta terpa angin, b). Tempat sapi beristirahat dengan nyaman, c). Memudahkan 
pelaksanaan pemeliharaan terutama dalam pemberian pakan dan minum serta pengawasan kesehatan.

\section{d. Pengendalian Penyakit}

Dalam pengendalian penyakit petani peternak selalu menghubungi petugas lapangan (keswan) apabila terdapat kendala serangan penyakit. Secara rutin petani peternak sudah menetapkan vaksinasi yang berkala, selain itu petani peternak selalu menjaga sanitasi lingkungan yang mana ternak selalu bersih dan kotoran ternak dibuang dua kali sehari bagi ternak yang di kandangkan terus menerus dan satu kali bagi ternak yang digembalakan. Hal ini sesuai dengan pendapat Abidin ( 2005 ) bahwa salah satu upaya pencegahan penyakit adalah dengan vaksinasi berkala dengan menjaga kebersihan sapi beserta kandangnya.

\section{e. Pemasaran}

Ternak yang digemukkan atau hendak dijual maka petani peternak akan menjualnya ke pasar ternak yang berada di nagari tersebut. Hal ini berarti rantai tata niaga pemasaran ternak menjadi pendek dengan arti kata memperbesar tingkat keuntungan bagi peternak dan mengurangi biaya perantara produsen dengan konsumen.

\section{KESIMPULAN DAN SARAN}

Masyarakat nagari Lurah Ampalu mempunyai antusias yang tinggi untuk mendapatkan informasi baru terhadap perkembangan teknologi baik di bidang pertanian maupun di bidang peternakan. Walaupun tingkat pendidikan dari masyarakat daerah ini masih rendah tapi tingkat pengalaman dalam berusaha ternak sudah cukup lama. Untuk masa yang akan dating masyarakat nagari Lurah Ampalu sangat berharap untuk ada pertemuan yang berkelanjutan baik dari team maupun dari pihak universitas untuk mengadakan kegiatan baik itu berupa penelitian maupun pengabdian masyarakat.

\section{DAFTAR PUSTAKA}

Devendra, C, 1977. Ultizationof Feedingstuffs from The Oil Palm. Dalam Feedingstuffs For Livestock I South Easst Asia, Malaysia.

Fridarti, N. Novirman, M.Zen, R.S.W. Ningrat. 2016. Condition rumen fluid characterisctics from effect indigenous microorganisms in fermentation cocoa waste. The International Journal of Science \& Technoledge, 4 (12) 88-93.

Fridarti dan S. Mulyani. 2017. Activity microorganisms increase Quality fermentation rind cocoa and characteristics fluid rumen. Prossiding Seminar Internasinal ADRI 7 th, 4-5 Februari 2017, pp 1-4 
Higa. T. 1996. An Earth Saving Revolution a Mean to Resave Our World Problem Through Effective Microorganisme (EM4). Edisi ke II. PT. Sanggolangit Persada, Jakarta.

Shurtleff, W and A. Aoyogi. 1979. The book of Tempeh: A Supersoy Food from Indonesia. Harper and Row, New York.

Syaiful F.L, D.T. Diva dan M. Hafizoh. 2020. Penerapan teknologi amoniasi jerami sebagai pakan alternatif sapi potong di Kenagarian Sungai Kunyit, Solok Selatan. Jurnal Hilirisasi IPTEKS, Vol. 3 No. 1, Maret 2020.

Syaiful F.L, dan F. Agustin. 2019. Diseminasi teknologi pakan komplit berbasis bahan baku lokal pada sapi potong di daerah Kinali Pasaman Barat. Jurnal Hilirisasi IPTEKS, 2(1): Maret 2019

Wong, H.K. and O.A. Hasan. 1988. Nutrive value and rument fermantation profile of sheep on fresor diets mardi, Res. J, 16(2): 147-154. 